\title{
Peningkatan Kapasitas Guru Geografi Memanfaatkan Media Pembelajaran Daring dan Luring di Masa Covid 19
}

\author{
Siti Dahlia*1, Tricahyono Nurharsono² ${ }^{2}$ Agung Adiputra ${ }^{3}$ \\ 1,2,3 Pendidikan Geografi, Universitas Muhammadiyah Prof. DR. Hamka \\ *e-mail: sitidahlia@uhamka.ac.id ${ }^{1}$,tricahyononurharsono@gmail.com ${ }^{2}{ }_{\text {_agung.georeg@gmail.com }}^{3}$
}

\begin{abstract}
Indonesia is one of many countries which experiencing the impact of the Corona virus or Covid-19. The goverment give recommendation for community to do a physical distancing as an effort breaking the chain of transmission. That condition has impact for education sector, it is the school close. Based on that, the learning process is done remotely from home. This condition raises problems related to learning methods. The aim of this articel to discuss how to improve capacity of geography teacher utilizing online and offline learning in the Covid 19 periode. The method was conducted on the programme that is lecture, workshop, and discuss. The program was carried out on 22 April, 2020 with the zoom application. The participants in the event consisted of 47 teachers. The result of programme discussed about the problem of study frome home, learning project, kinds of learning platform of online and offline, and Ina Risk aplication. To motivating of students and also reduce the saturation on the learning process the teacher can also be done with multimedia-based games such as: Monopoli, Work Sheet, Instagram, and Snakes and ladders games.
\end{abstract}

Keywords: Geography Teacher, Online and Offline Learning, Covid 19.

\begin{abstract}
Abstrak
Indonesia adalah salah satu Negara yang terdampak virus Covid 19, sehingga pemerintah menganjurkan untuk menjaga jarak kepada masyarakat dalam rangka memutus mata rantai penularan. Hal tersebut berdampak salah satunya pada aspek pendidikan, yaitu sekolah dalam beberapa periode di tutup. Kondisi tersebut mengharuskan proses pembelajaran secara jarak jauh yaitu melalui jaringan atau online. Akan tetapi, kondisi tersebut memunculkan berbagai kendala dalam pembelajaran salah satunya metode pembelajaran. Untuk itu, tujuan artikel ini mengkaji terkait peningkatan kapasitas guru geografi dalam memanfaatkan media pembelajaran secara online dan offline di masa pandemic Covid 19. Metode pelaksanaan kegiatan yang digunakan yaitu ceramah, workshop, dan diskusi. Pelaksanaan kegiatan pada 22 April 2020 melalui aplikasi zoom, yang terdiri dari 47 peserta. Hasil kegiatan berupa mengkaji terkait permasalahan proses pembelajaran di rumah secara online, jenis platform pembelajaran secara online dan offline, dan aplikasi Ina Risk. Pada kegiatan pengabdian melatih guru terkait proses pembelajaran untuk memotivasi siswa dan mengurangi kejenuhan dalam pembelajaran melalui multimedia melalui berupa permainan seperti: monopoli geografi, lembar kerja, instagram, dan ular tangga.
\end{abstract}

Kata kunci: Guru Geografi, Pembelajaran Online dan Offline, Covid 19

\section{PENDAHULUAN}

Coronavirus Disease 2019 atau COVID-19 adalah penyakit baru yang dapat menyebabkan gangguan pernapasan dan radang paru. Penyakit ini disebabkan oleh infeksi Severe Acute Respiratory Syndrome Coronavirus 2 (SARS-CoV-2). Dari berbagai penelitian, metode penyebaran utama penyakit ini diduga adalah melalui droplet saluran pernapasan dan kontak dekat dengan penderita. Covid 19 pertamakali dilaporkan oleh pemerintah Cina di Wuhan pada tangal 31 Desember 2019, yang selanjutnya menyebar ke seluruh dunia dan menjadi masalah darurat kesehatan international (Kang, Choi, Kim, \& Choi, 2020). Pemerintah di Indonesia pertama kali melaporkan bahwa penduduk Indonesia positif Covid 19 pada tangal 2 Maret 2020 yang menimpa dua orang (Kompas, 2020). Indonesia merupakan negara dengan jumlah penduduk terbanyak ke empat di dunia, sehingga diprediksi akan mengalami dampak Covid 19 lebih lama dibandingkan negara dengan penduduk yang lebih sedikit (Djalante et al., 2020). Selain itu, Indonesia sebagai Negara berkembang dengan tingginya arus urbanisasi dan adanya 
konsentrasi kepadatan penduduk mengakibatkan sulit dalam pencegahan Covid 19 (Zhou et al., 2020).

Kasus positif virus Corona (COVID-19) di Indonesia mencapai angka 9.771 pada tangal 29 April 2020. Kasus positif COVID-19 pada Bulan Maret sampai April 2020 paling banyak berasal dari DKI Jakarta, sehingga Jakarta menjadi episentrum persebaran virus corona (detiknews, 2020). Kasus terkonfirmasi Covid 19 di Jakarta tertangal 29 April 2020 yaitu 4.033 kasus positif, 2.002 dirawat, 412 sembuh, 381 meningal, dan 1.238 isolasi mandiri (https://corona.jakarta.go.id/id). Di Jakarta Covid 19 sejak 15 Maret 2020 mengakibatkan system bekerja dari rumah atau Work Form Home (WFH). Pada tangal 10 April 2020 untuk memutus rantai pernyebaran virus korona Gubernur DKI Jakarta mengeluarkan pertauran Pembatasan Sosial Berskala Besar (PSBB), sehingga masyarakat dianjurkan stay at home dan physical distancing. Hal ini berdampak pada berbagai aspek salah satunya bidang pendidikan, yaitu proses pembelajaran berlangsung di rumah. Kondisi penutupan sekolah berdampak pada pendidikan $80 \%$ anak di belahan dunia, dalam jangka panjang kondisi tersebut dapat merugikan kondisi social dan kesehatan anak serta cendrung meningkatkan kondisi ketidaksetaraan (Van Lancker \& Parolin, 2020). Kondisi penutupan sekolah dapat berdampak terhadap kehidupan social, pendidikan, dan kesehatan mental anak (Fantini, Reno, Biserni, Savoia, \& Lanari, 2020).

Pendidikan mempunyai tanggungjawab besar untuk menyiapkan generasi yang mampu berperan aktif dalam pembangunan Negara Indonesia yang luas dengan beribu-ribu pulau serta banyaknya fenomena bencana alam. Melalui mata pelajaran di sekolah, generasi mendatang mendapatkan wawasan, pengetahuan, dan ketrampilan hidup untuk masa mendatang (Susilawati \& Sunarhadi, 2017). Perwujudan pendidikan yang berkualitas menjadi tanggung jawab semua pihak, terutama adalah tanggung jawab pelaksana pembelajaran di sekolah. Untuk mengatasi era globalisasi dalam dunia pendidikan, upaya memenuhi kebutuhan, keberadaan dan keprofesionalan guru harus terus menerus ditingkatkan (Suharini, 2014). Kualitas pembelajaran merupakan ukuran yang menunjukkan seberapa tinggi kualitas interaksi antara guru dengan siswa dalam proses pembelajaran khususnya dalam pembelajaran geografi. Oleh karena itu, keberhasilan proses pembelajaran sangat tergantung pada: guru, siswa, sarana pembelajaran, lingkungan kelas, dan budaya kelas (Syarif, 2018).

Pada kondisi Covid 19 ini guru yang sudah memiliki tanggung jawab tinggi, harus dihadapkan dengan merubah metode dan model pembelajaran yang beradaptasi dengan kondisi belajar di rumah atau jarak jauh. Kondisi tersebut memberikan tantangan kepada guru untuk mampu penggunaan media pembelajaran secara konvensional menjadi online. Hal ini karena pada masa Covid 19 pembelajaran berbasis online tidak dapat dihindari (Astini, 2020; Farah \& Nasution, 2020; dan Khasanah, Pramudibyanto, \& Widuroyekti, 2020). Pada saat ini terdapat banyak platform yang dapat mendukung pembelajaran secara online, seperti: Google Classroom, Zoom, Edmodo, rumah belajar, scholoogy, Whatsapp Grup, dan lainnya. Akan tetapi, hasil penelitian menunjukkan pembelajaran dalam jaringan memiliki hambatan seperti; belum adanya fasilitas seperti laptop, penguasaan teknologi, jaringan internet (Suni Astini, 2020; dan Khasanah et al., 2020). Kondisi tersebut mengakibatkan belum maksimalnya capaian pembelajaran, apalagi materi geografi terdapat beberapa tema yang membutuhkan analisis hitungan dan praktikum. Selain itu, pembelajaran geografi berkaitan dengan kondisi geosfer yaitu berkaitan dengan lingkungan dan alam. Untuk itu, penting memberikan dorong kepada guru geografi terkiat media pembelajaran pada masa pandemi. Berdasarkan hal tersebut, artikel ini bertujuan untuk membahas terkait upaya peningkatan kapasitas guru geografi memanfaatkan media pembelajaran secara online dan offline pada masa Covid 19.

\section{METODE}

Sasaran pelaksanaan kegiatan pengabdian masyarakat yaitu guru-guru geografi di Jabodetabek dengan jumlah peserta 47 orang (Gambar 1). Selain itu, pada kegiatan di hadiri peserta yang bekerja di Dinas Survei Poto Udara Angkatan Udara, dan Dinas Pendidikan dan 
Kebudayaan Provinsi Banten. Waktu pelaksanaan kegiatan tangal 22 April 2020, pukul 13.0016.00 WIB melalui webinar dengan aplikasi zoom. Narasumber kegiatan yaitu Drs. Tricahyono, M.Si (Dosen pendidikan Geografi UHAMKA), Agung Adi Putra, M.Si (Dosen pendidikan Geografi UHAMKA), dan Tasril (Praktisi BNPB).

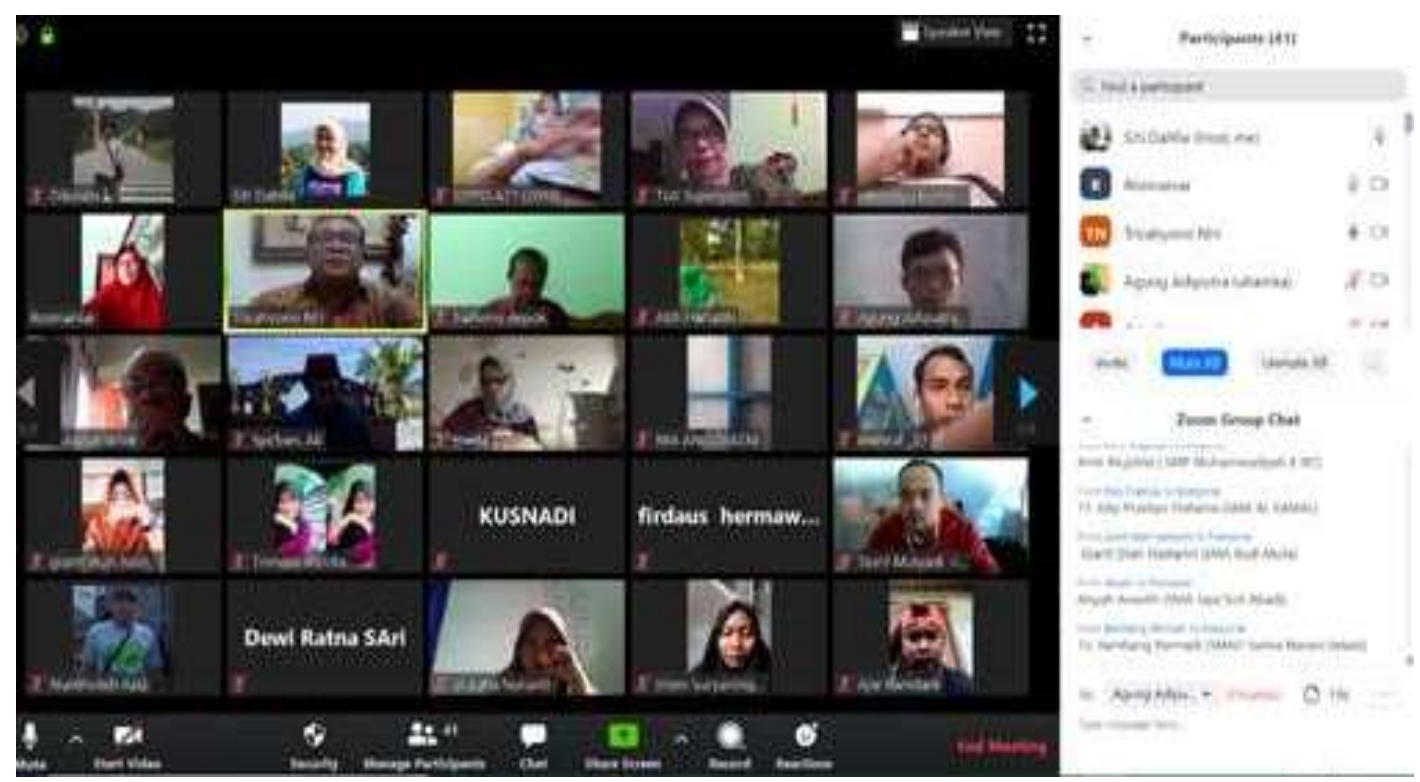

Gambar 1. Peserta Webinar Pengabdian Pelatihan Media Pembelajaran

Metode pelaksaaan kegiatan untuk penyelesaian masalah atau solusi untuk mitra terkait metode dan media pembelajaran yaitu ceramah, diskusi, dan pelatihan (Tabel 1). Metode ceramah pada kegiatan webinar narasumber menyampaikan terkait platform-platform media pembelajaran yang dapat digunakan di masa Pandemi Covid 19, diskusi dalam konteks kegiatan ini yaitu peserta memberikan informasi kendala dalam proses pembelajaran, dan pelatihan yaitu peserta diberikan kesempatan menggunakan platform untuk media pembelajaran.

Tabel 1. Metode Penyelesaian atau Solusi Permasalahan Mitra

\begin{tabular}{clll}
\hline No & \multicolumn{1}{c}{$\begin{array}{c}\text { Aspek } \\
\text { Permasalahan }\end{array}$} & $\begin{array}{l}\text { Pendekatan } \\
\text { Solusi }\end{array}$ & \multicolumn{1}{c}{ Implementasi } \\
\hline 1 & Metode & Ceramah, & Metode berbasis Project, \\
& Pembelajaran & $\begin{array}{l}\text { Diskusi dan } \\
\text { Pelatihan }\end{array}$ & Game, dan Mapping \\
2 & Media Pembelajaran & $\begin{array}{l}\text { Ceramah, } \\
\text { Diskusi dan } \\
\text { Pelatihan }\end{array}$ & $\begin{array}{l}\text { Platform online dan } \\
\text { offline }\end{array}$ \\
& & & \\
\hline
\end{tabular}

Untuk tahapan - tahapan pada kegiatan pengabdian masyarakat disajikan pada Gambar 2 , yang teridiri dari tahapan persiapan, tahapan pelaksanaan, dan tahapan evaluasi. Pada tahapan persiapan merupakan tahapan penentuan jadwal kegiatan, koordinasi dengan mitra, penentuan narasumber, dan bahan serta peralatan pendukung kegiatan. Pada tahapan pelaksanaan merupakan tahapan pelatihan dan berdiskusi terkait media pembelajaran geografi berbasis platform online dan offline. Pada tahap evaluasi merupakan tahapan identifikasi pemahaman peserta dan masukan mitra terhadap pelaksana kegiatan, serta publikasi kegiatan melalui 
youtube, yaitu sebagai berikut; https://youtu.be/-yW7SmZmS4k dan website: https://fkip.uhamka.ac.id/galery-kegiatan/diskusi-daring-media-pembelajaran-geografi-dimasa-covid-19-program-studi-pendidikan-geografi-uhamka/.

Tahap Persiapan
-Menentukan jadwal
rencana kegiatan
- Koordinasi dan
membuat surat
pernyataan kerja sama
dengan mitra
- Mengundang mitra
-Menyiapkan
narasumber, alat,
bahan, dan materi
kegiatan.

Tahap Pelaksanaan
- Problematikan dan
hasil riset terkait
pembelajaran di rumah
selama Covid 19
- Pembelajaran berbasis
project
- Platform Pembelajaran
Secara Online dan
Offline
-Ina Risk
- Diskusi dan Tanya
Jawab

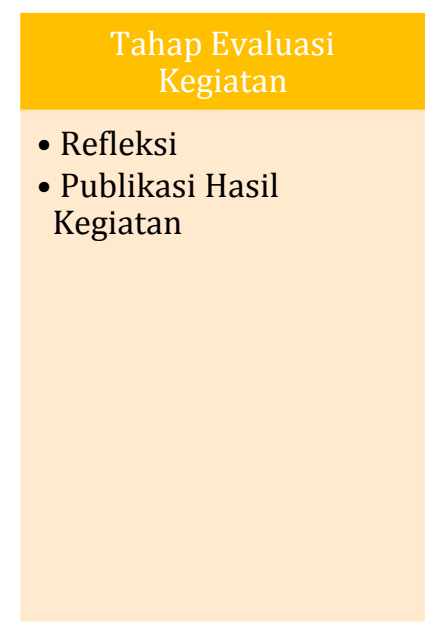

Gambar 2. Tahapan Kegiatan Webinar Pengabdian Masyarakat Pelatihan Media Pembelajaran

Sebagai bahan evaluasi kegiatan dan identifikasi permasalahan proses belajar mengajar di sekolah kami menggunakan metode FGD dengan peserta, serta googel form. Hasil evaluasi di dientifikasi secara deskriptif terkait temuan kondisi di lapangan.

\section{HASIL DAN PEMBAHASAN}

Pada pelaksanaan kegiatan pengabdian masyarakat terdiri dari berbagai kegiatan yaitu: problematika Work Form Home (WFH), pembelajaran berbasis project, platform pembelajaran secara online dan offline, dan Ina Risk.

\section{Problematika Work Form Home (WFH)}

Pada sesi ini narasumber melakukan FGD dengan peserta kegiatan terkait problematika proses pembelajaran dari rumah. Hasil informasi dari peserta kegiatan bahwa terdapat permasalah yang muncul selama proses pembelajaran di rumah yaitu infrastruktur jaringan berupa keterbatasan kuota, adaptasi bagi guru khususnya guru yang berada pada usia lanjut, alat ukur yang belum teridentifikasi dalam mengukur outcome, serta daya serap siswa. Hasil pernyataan ini sesuai dengan hasil penelitian sebelumnya bahwa terdapat beberapa sekolah dan siswa terbatas akses internet, dan hasil survey menunjukkan bahwa 50\% mahasiswa yang belum mempunyai laptop, $80 \%$ mahasiswa menyatakan susah mendapatkan sinyal dan boros penggunaan paket data ini disebabkan karena banyak mahasiswa yang tinggal jauh dari daerah perkotaan, Perkuliahan dirasa kurang efektif karena sebanyak 61,5\% mahasiswa yang menyatakan belum pernah menggunakan media perkuliahan online (Suni Astini, 2020).

\section{Pembelajaran Berbasis Project}

Pembelajaran berbasis project merupakan salah satu soluasi yang ditawarkan pada masa Covid 19 ini. Hal ini lebih bersifat pembelajaran secara Blanded learning, yaitu pencampuran model pembelajaran konvensional dengan belajar secara online (Amin, 2017). Hal ini dilakukan untuk mengurangi keterbatasan kuota dari siswa. Sebagai contoh, proses kegiatan pembelajaran berbasis project secara multimedia yaitu menyusun Geopoli sebaran fauna dan game ular tangga 
Negara manju (Gambar 3). Selain itu, selama WFH untuk memotivasi siswa dan mengurangi kejenuhan proses pembelajaran juga dapat dilakukan dengan game berbasis multimedia (Gambar 4).

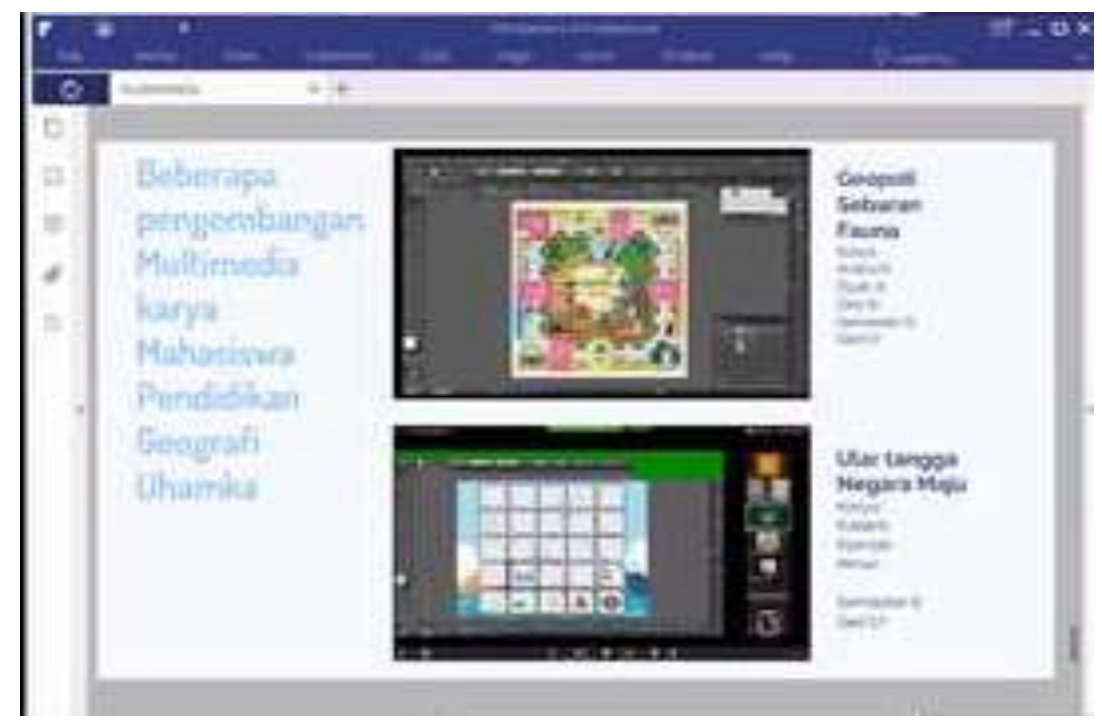

Gambar 3. Materi Pembelajaran Berbasis Project

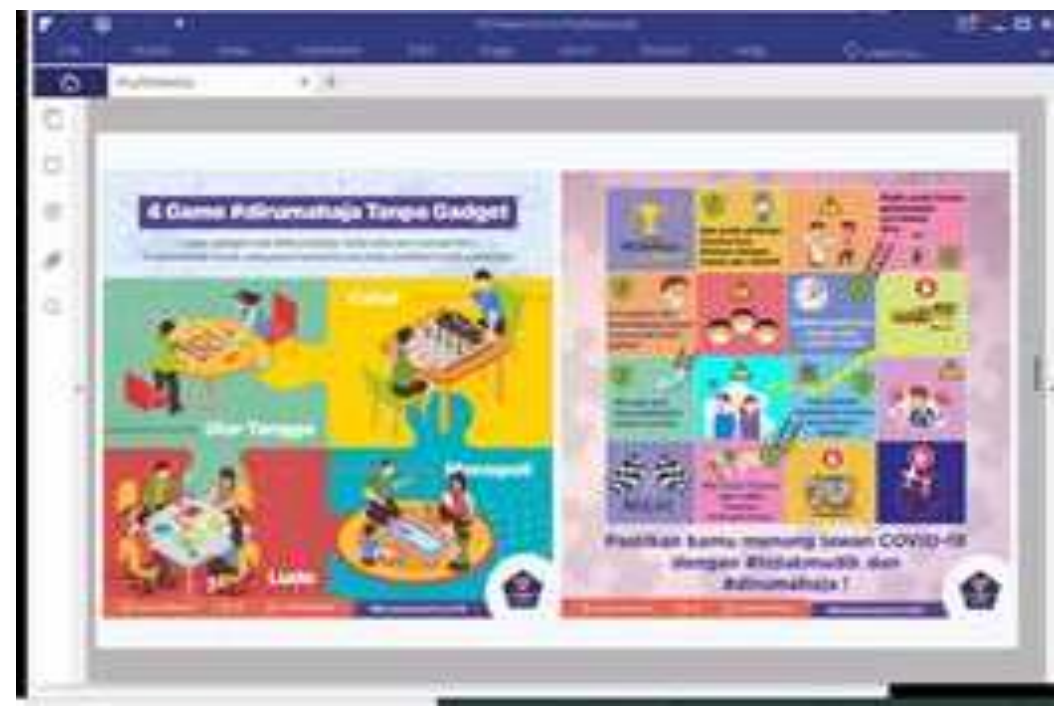

Gambar 4. Pembelajaran Berbasis Game

\section{Platform Pembelajaran Secara Daring dan Luring}

Penggunaan multimedia dalam proses pembelajaran geografi diharapkan untuk menghasilkan outcome sesuai tujuan pembelajaran dapat dilaksanakan bersifat menyenangkan, fleksibel, dan solutif. Untuk itu, proses pembelajaran geografi selama WFH terdapat platform yang digunakan baik secara online dan offline. Platform online berupa google class room, Edmodo, Schoology, OpenOLAT, Moodle, Khan Academy, kahoot, Ruang Guru, Instagram, Youtube, dan lainlain. Platform offline secara geografi dapat menggunakan boardgame berupa media permainan 
seperti monopoli, atlas, dan globe. Selain itu, proses pembelajaran dapat berupa game menggunakan work sheet (Gambar 5).

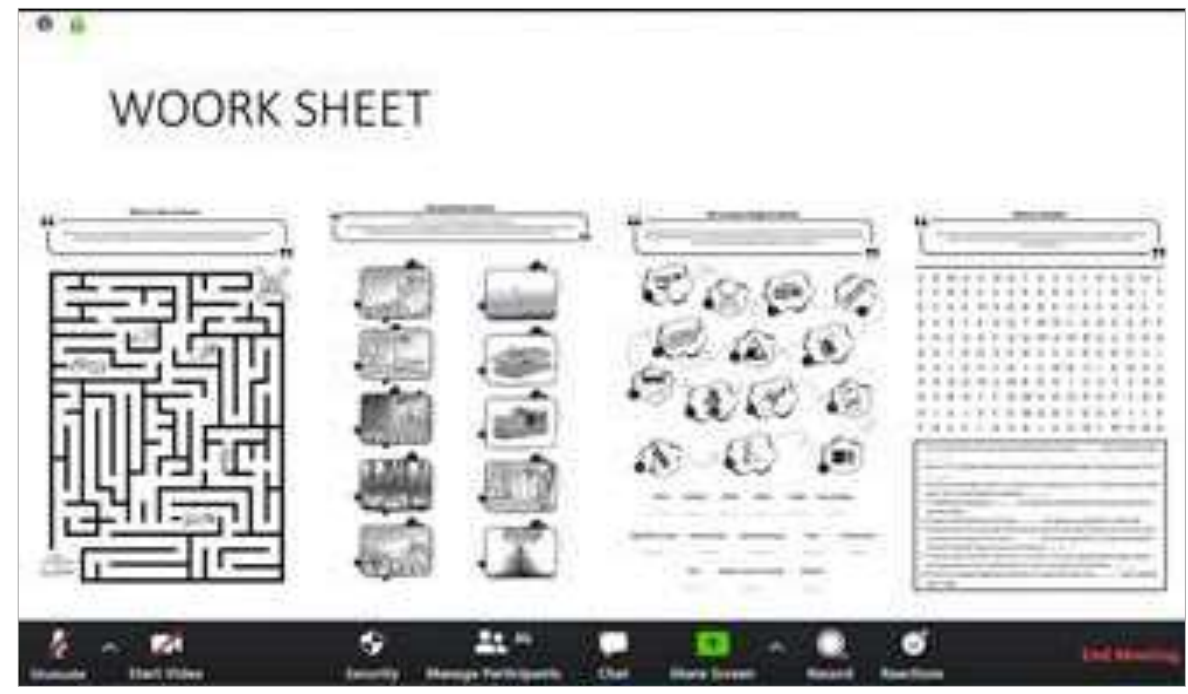

Gambar 5. Media Pembelajaran Woork Sheet

4. Ina Risk

Selama Covid 19 ini, selain platform-platform diatas terdapat media pembelajaran yang di dukung oleh BNPB sebagai wujud peningkatan pemahaman siswa terkait bencana Covid 19 yaitu melalui aplikasi inaRISK (Gambar 6). Aplikasi inaRISK merupakan aplikasi yang dapat digunakan untuk melihat lokasi siswa terhadap bencana. Hal ini diharapkan siswa dapat belajaran dengan menyenangkan, serta meningkatkan pengetahuan siswa terhadap kondisi bencana lingkungan sekitar. Hasil FGD dengan peserta kegiatan, peserta belum memanfaatkan aplikasi ini dalam pembelajaran sehingga dapat dijadikan bahan rujukan.

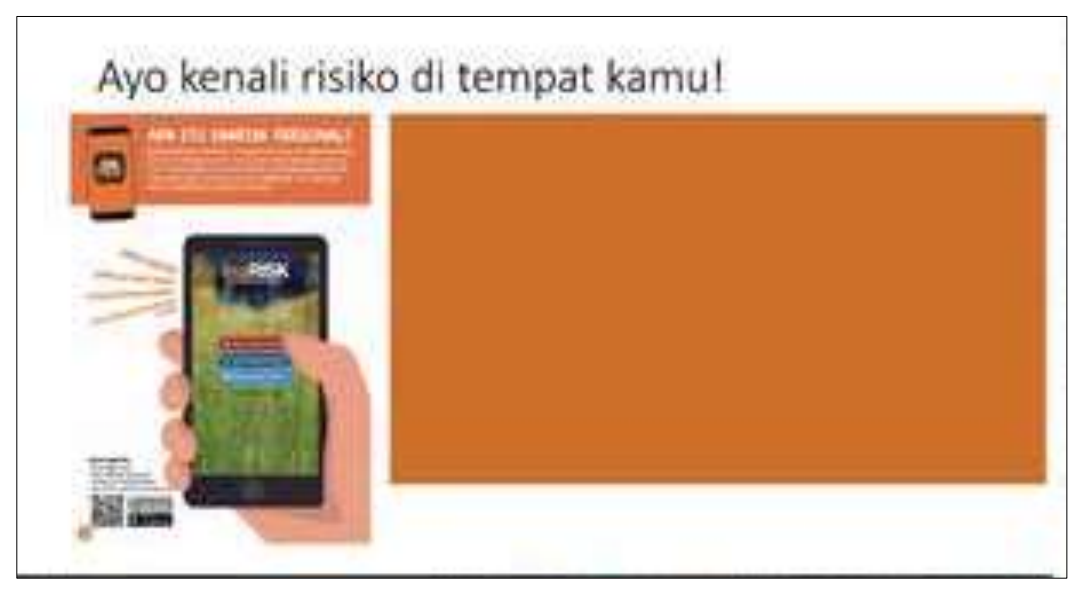

Gambar 6. Pemanfaatan Aplikasi InaRISK dalam pembelajaran

\section{KESIMPULAN}

Mitra yang menjadi sasaran kegiatan pengabdian masyarakat ini merupakan Guru Pendidikan Geografi di Jabodetabek. Permasalahan mitra yaitu pada kondisi Covid 19 untuk memutus perkembangan penularan virus corona, maka kebijakan pemerintah berupa Work Form Home. Hasil FGD dengan peserta kondisi tersebut berdampak juga terhadap proses pembelajaran, yang mengakibatkan munculnya problematika-problematika dilapangan salah satunya media 
pembelajaran yang digunakan oleh guru. Hal ini dipengaruhi oleh factor infrastruktur jaringan, keterampilan guru, fasilitas dan lainnya. Untuk itu, pada Program Kemitraan Masyarakat ini memberikan kesempatan untuk berbagi media pembelajaran yang dapat digunakan oleh guru geografi pada masa Covid 19 melalui Webinar Zoom. Pada kesempatan diskusi di ikuti oleh 47 peserta. Materi diskusi berupa tantangan dan problem di masa Covid 19, Platform Pembelajaran secara online dan offline, Ina Risk, dan Work Sheet.

\section{UCAPAN TERIMA KASIH}

Program Pengabdian Kepada Masyarakat merupakan Program terencana dalam memenuhi kewajiban Catur Dharma Perguruan Tinggi. Pada kesempatan ini kami mengucapkan termimakasih kepada LPPM UHAMKA sebagai lembaga yang menaungi program, Program Studi Pendidikan Geografi UHAMKA selaku tim kegiatan, dan Mitra yaitu guru-guru Pendidikan Geografi di lingkungan Jabodetabek.

\section{DAFTAR PUSTAKA}

Amin, A. K. (2017). Kajian Konseptual Model Pembelajaran Blended Learning berbasis Web untuk Meningkatkan Hasil Belajar dan Motivasi Belajar. Jurnal Pendidikan Edutama, 4(2), 51-64. Retrieved from https://ejurnal.ikippgribojonegoro.ac.id/index.php/JPE/issue/view/12

Astini, N. K. S. (2020). Pemanfaatan Teknologi Informasi dalam Pembelajaran Tingkat Sekolah Dasar pada Masa Pandemi Covid-19. Jurnal Lampuhyang, 11(2), 13-25. Retrieved from http://e-journal.stkip-amlapura.ac.id/index.php/jurnallampuhyang/article/view/194/125.

Djalante, R., Lassa, J., Setiamarga, D., Sudjatma, A., Indrawan, M., Haryanto, B., ... Warsilah, H. (2020). Review and analysis of current responses to COVID-19 in Indonesia: Period of January to March 2020. Progress in Disaster Science, 6, 100091. https://doi.org/10.1016/j.pdisas.2020.100091

Fantini, M. P., Reno, C., Biserni, G. B., Savoia, E., \& Lanari, M. (2020). COVID-19 and the re-opening of schools : a policy maker 's dilemma. Italian Journal of Pediatrics, 46(79), 10-12.

Farah, B., \& Nasution, R. D. (2020). Analisis Perubahan Orientasi Pola Hidup Mahasiswa Pasca Berakhirnya Masa Pandemi Covid-19. Jurnal Noken: Ilmu-Ilmu Sosial, 5(2), 23. Retrieved from http://ejournal.um-sorong.ac.id/index.php/jn/article/view/968

Kang, D., Choi, H., Kim, J. H., \& Choi, J. (2020). Spatial epidemic dynamics of the COVID-19 outbreak in China. International Journal of Infectious Diseases: IJID: Official Publication of the International Society for Infectious Diseases, 94(January), 96-102. Retrieved from https://doi.org/10.1016/j.ijid.2020.03.076

Khasanah, D. R. A. U., Pramudibyanto, H., \& Widuroyekti, B. (2020). Pendidikan Dalam Masa Pandemi Covid-19. Jurnal Sinestesia, 10(1), 41-48. Retrieved from https://sinestesia.pustaka.my.id/journal/article/view/44

Suharini, E. (2014). Studi Tentang Kompetensi Pedagogik Dan Profesional Bagi Guru Geografi Di SMA Negeri Kabupaten Pati. Jurnal Geografi, 11(2), 148-164. Retrieved from https://journal.unnes.ac.id/nju/index.php/JG/article/view/99

Suni Astini, N. K. (2020). Tantangan Dan Peluang Pemanfaatan Teknologi Informasi Dalam Pembelajaran Online Masa Covid-19. Cetta: Jurnal Ilmu Pendidikan, 3(2), 241-255. Retrieved from http://jayapanguspress.penerbit.org/index.php/cetta/article/view/452/4

Susilawati, S. A., \& Sunarhadi, M. A. (2017). Implementasi Model Peta (Pembelajaran Kompetensi Spasial) Dalam Mata Pelajaran Geografi Bagi Guru Sma Di Kabupaten Sukoharjo Jawa Tengah. Warta LPM, 20(2), 128-137. Retrieved from http://journals.ums.ac.id/index.php/warta/article/view/4530

Syarif, E. (2018). Dinamika Pembelajaran Geografi Di Sman 9 Takalar Sulawesi Selatan. CENDEKIA: Journal of Education and Teaching, 12(2), 75-84. Retrieved from https://cendekia.soloclcs.org/index.php/cendekia/article/view/519 
Van Lancker, W., \& Parolin, Z. (2020). COVID-19, school closures, and child poverty: a social crisis in the making. The Lancet Public Health, 5(5), e243-e244. Retrieved from http://dx.doi.org/10.1016/S2468-2667(20)30084-0

Zhou, C., Su, F., Pei, T., Zhang, A., Du, Y., Luo, B., ... Xiao, H. (2020). COVID-19: Challenges to GIS with Big Data. Geography and Sustainability, 1(1), 77-87. https://doi.org/10.1016/j.geosus.2020.03.005

https://news.detik.com/berita/d-4996024/sebaran-9771-kasus-positif-corona-di-34-provinsidki-jakarta-terbanyak

https://nasional.kompas.com/read/2020/03/03/06314981/fakta-lengkap-kasus-pertamavirus-corona-di-indonesia?page=all 